Wiseman, P. (2019) Lifting the Lid: Disabled toilets as sites of belonging and embodied citizenship. Sociological Review, 67(4), pp. 788-806. (doi:10.1177/0038026119854255)

There may be differences between this version and the published version. You are advised to consult the publisher's version if you wish to cite from it.

\title{
http://eprints.gla.ac.uk/189604/
}

Deposited on: 3 July 2019

Enlighten - Research publications by members of the University of Glasgow http://eprints.gla.ac.uk 


\title{
Lifting the Lid: Disabled Toilets as Sites of Belonging and Embodied Citizenship
}

\section{Phillippa Wiseman}

\begin{abstract}
This paper explores the complex relationship between citizenship, bodies and toileting through the experiences of disabled people. By examining the toiletscapes that disabled people must navigate, the impact that inaccessible toilets have on self and personhood and the hidden inequalities produced through these spaces we can come to understand disabled people's sense of (non)belonging. At the centre of this paper is a focus on the socio-political dualisms that locate disabled people at the margins of everyday citizenship and through a feminist phenomenological analysis the toilet and toileting bring to the fore how (non)belonging is felt. Toilet(ing), then, problematises the nature of so-called 'private' and 'public' spaces and by engaging bodily waste we come to understand citizenship through dirt.
\end{abstract}

Keywords: Disability, Belonging, Toilets, Citizenship, Embodiment, UK

\section{Introduction}

There is a well-documented history of disabled people's exclusion from public space, their political struggles for equality and full citizenship (Barnes \& Mercer 1997; Crow 1996; Morris 2005; Oliver 1990; Shakespeare 2014). There is also a welldocumented critique of the history that examines the longstanding neglect of disabled people's 'private' lives, including their corporeal realities and the messiness or 'dirtiness' of managing impairment in everyday life (Crow 1996; Hughes \& Paterson 1999; Shakespeare \& Watson 2002; Thomas 1999). There has, further still, been a curious neglect of toilets; arguably one of the most fundamental spaces in which being human is acted out and spaces that are of particular concern to disabled people. This neglect is characterised here through the idea of the 'toiletscape' which frames toileting and toilet spaces as overwhelmingly ableist. That is, the toiletscape in the UK is one that excludes disabled people and produces hidden and pervasive 
inequalities. That it is a toilet -scape draws directly from Appadurai's (1990) notion that landscapes are shifting, experienced in myriad ways but inherently structured through globalised power. For nondisabled people, disabled toilets may represent inclusion, equal and fair provision and for many disabled people, disabled toilets are the sites of their nonbelonging (see Terreni-Brown this volume).

Everyone everywhere defecates in some way, form, space or another. Experiences of access to toilets in both public and private spheres, I argue, says a lot about both how our bodies are perceived, and our citizenship imagined. The relationship between toileting, citizenship and belonging shall be the focus of this paper. I did not set out to 'talk about toilets' in my research; the doctoral study, from which this data is drawn, focused on broader experiences of disabled young people, of embodied citizenship with a particular focus on everyday intimacies. However, I was talked to about toilets extensively and by nearly every participant that I interviewed. The experiences of and barriers to using public and private toilets were intrinsically bound around how participants viewed their embodied selves and their constructions of belonging and citizenship. This forms the backbone of the discussion. In essence, toilets are at the centre of what it means to belong, to fee/ included, valued and of worth.

\section{Putting Toilets in Context}

A large proportion of the global population have no access to toilet facilities (Chalfin 2014). This has implications for sexual violence against women and girls (Abrahams et al 2006), as well as public and global health issues and has become central to gender and transgender equality (Cavanagh 2011). As Plaskow notes the distribution, quality, and structure of public toilets are both symbols and concrete representation of a larger system of social hierarchies' (Plaskow, 2008, p52). Where we have seen struggles for social justice and equality we have also seen lack of equal access to toilets as part of these campaigns (Plaskow 2008). Surprisingly, however, defecatory inequalities are less apparent in the disability literature. Whilst there are toilet campaigns in the UK for disability toilet equality and provision ${ }^{1}$, there

\footnotetext{
${ }^{1}$ http://www. changing-places.org/
} 
remains a tangible lack of appropriate and inclusive public toilet provision for disabled people. Until confronted, by participants, with stories of exclusion, of being 'caught short' and restricting consumption of food and fluids - I admittedly hadn't thought about the political and social importance of accessible toilets for disabled people.

The focus on gender and unequal toilet provision has, usefully; brought to the fore the fact that toilets are personal and political - toilets breach the distinctions made between 'private' and 'public life'. Plaskow (2008) argues that the absence of women's toilets neatly reflects the absence of women from public power. I argue that the same is emphatically true for disabled people.

This paper seeks to form a bridge between multiple, seemingly disparate (but intersecting) paradigms at the core of which is 'the toilet'. When I was reflecting on how to bring toilets, belonging and citizenship, together I realised, through participant narratives, that poor or no provision to do what all people must do is fundamentally destructive to a person's sense of self, value and personhood. This is why pissing, shitting and where we piss and shit are important - not only in the disposal of the body products we find socially embarrassing or disgusting but because they are inextricably linked to what it means to have social value - to belong. Toilets are relational, Pickering reminds us (2010), and they connect us materially and symbolically to everyday life, to the state, and to others in myriad complex ways.

Toileting, then, is intersectional. The implications of toileting are simultaneously global and local; increasingly recognised as being at the centre of what it means to have fundamental human rights. The neglect of toilets in the disability literature reflects a wider neglect or absence of toilets in the academy more generally. The study of processes of elimination and the products of the body that are discharged can be explained, in part, by the 'absent presence' of the body in sociology and limited engagement with the 'private' and 'personal' spheres of disabled peoples' lived experience (Shilling 2012; Hughes \& Paterson 1999). Furthermore, citizenship 
has been separated from our corporeal activities, and bodies have been removed from models of citizenship (Bacchi \& Beasley 2000; see also Giddens 1991). Therefore, some work has to be done to develop the notion that the toilet is the or rather 'a'seat of citizenship.

\section{What is it about toilets? Toilets and citizenship}

Why talk about toilets? What is it about toilets that form a suitable category of analysis for social inequality and injustice? Toilets are so ubiquitous they are almost socially 'invisible', they are hidden from view, physically, behind stalls and cubicles and locked doors. They are hidden from our everyday conversations; the process of eliminating waste is so unacceptable a topic of discussion we relegate the most universal of human activities to silence or uncomfortable 'toilet humour'. Thus, the inequalities around the toilet are similarly hidden. Manners, waste and 'dirt' - their removal from acceptable social life - have been tackled historically through the work of Elias (2000) who described, in essence, a good and moral citizen as one who adhered to a process of 'civilising' the body - a simultaneous process of shame and embarrassment directed at what bodies necessarily do. Douglas (1966) crucially explored disgust in relation to 'dirt' and the propensity to categorise and classify; 'dirt as matter out of place' explains the ability of our waste, of 'dirt', to disturb or upset orders of cleanliness and social acceptability.

Along with many seemingly 'private' aspects of embodied life and the intimacies of the everyday, toilets were moved to the very 'back regions' that Shilling (2012) refers to, in favour of the clean, the rational and the ordered. In my bid to 'pull together' disparate paradigms, it seems clear that the privatisation of toileting and bodily wastes intersects with a history of bodies, a history of classifying bodies, of dichotomous constructions of bodies and of excluding certain bodies from 'public' life. This civilising process meets with a history of impaired bodies; a story that ends in the rejection of corporeal vulnerability, volatility, leakiness and mess (Hughes, this volume). 
Bodies in modernity, are controlled bodies, they are 'able', and they are male; the 'modern' citizen is a citizen in control and crucially structured through an ideal of cleanliness. As Bauman (1997, p5) maintains, modernity can be articulated through 'a dream of purity', of classification and organisation and of the 'clean and hygienic' (Hughes 2002). Dichotomous approaches to bodies have resulted in what Greer (2006) refers to as 'a series of violent binaries (male/female; mind/body, reason/emotion, nature/culture)' and what Grosz (1994, p3) maintains is dichotomous social tendencies that 'necessarily hierarchizes and ranks the two polarised terms so that one becomes the privileged term and the other its supressed, subordinate, negative counterpart'. Crucially, then, 'the mind/body dichotomy... is not an arcane philosophical debate, but rather involved governmental rules and regulations that affect people's lives on a day-to-day basis' (Bacchi \& Beasley, 2000, p327).

The mind/body dualism has been most frequently mapped on to the lived realities of women's bodies and feminist literatures have highlighted their subsequent exclusion from citizenship. Similarly, the othering of bodies of colour (Mercer \& Race 1998) and their construction as 'out of control' and in opposition to Western rationalism, explores the dangerous consequences of ethnicity as defined through binary thought, reminding us always of Plaskow's (2008) assertion that campaigns for equality, for civil rights have seen toilets bound up with them. For example, the racial segregation of toilets through 'Jim Crow' laws (Weinburg 2009). The articulation of some bodies as less rational, less 'whole', and out of control has resulted in limited access to the 'public sphere':

There have been repeated attempts to limit women's civil, social and political rights by taking the male body, however defined, as 'complete' and the norm and by defining women as different and inferior as a result of their unstable bodies.

(Shilling, 2012, p59) 
The lives of disabled people and the inequalities they face on the basis of being defined by their bodies is less well explored in relation to the mind/body dualism, despite these same binary constructions forming the basis of the disability/impairment bifurcation. Whilst there is not the space, in this paper, to contend with the vast expanse of contested literatures and debates on citizenship and how it might be defined- it is essential to define the parameters of what I mean by citizenship in this context.

\section{Locating Embodied Citizenship}

Citizenship is a central pillar of disability scholarship; the exclusion and discrimination of disabled people is also the exclusion of disabled people from 'full citizenship' (Lister 2007). Disability scholarship made limited reference to citizenship studies and vice versa thus creating a paradigmatic gap where disabled people's lives have not been well represented in mainstream sociological scholarship. Similarly, the bifurcation of the public and private spheres, the bifurcation of experiences of disability and impairment and the distancing of embodiments from citizenship have left a space where hidden inequalities are pervasive.

Traditional models of citizenship are formed on constructions of productivity in the 'public' sphere; citizenship was defined through activities enacted in public spaces almost always by men (Plummer 2003, 52 see also Habermas 1989) and can be understood as 'defined precisely in terms of an identity state based upon rights and activities enacted in the national public arena as against those merely private personal activities in the domestic sphere' (Bacchi \& Beasley, 2000, p340). However, there has been a longstanding process of bringing bodies back in to citizenship, critically feminist scholarship has been central to this movement (Bacchi \& Beasley 2000,2002; Lister 2003) to broaden definitions of citizenship to address the lived realities of groups previously excluded, to explore what it means to belong.

\section{Citizenship as (non)belonging}

Citizenship is, essentially, about belonging - about being a part of the collective social fibre that forms everyday life. As May (2011) elucidates, society cannot be 
examined in isolation from the self; citizenship can be understood as connected to the self, and further still, as the material expression of belonging. For May (2011, p366) society, as I argue much like citizenship, is constituted through how people relate to their material environment. Honneth (2004, p342) (re)defines citizenship as being bound up with social recognition to promote the 'just society'. As such, recognition of the needs, identity and validity of others affords personhood and the result, arguably, is the phenomenological and sensorial experience of belonging or the feeling of belonging (see also Fraser \& Honneth 2003).

Belonging, argues Antonisch (2010), is poorly defined despite having academic attachments to identity or citizenship studies. Less focus is given to the phenomenological feeling of belonging, of feeling 'at home' (Yuval-Davis 2006 see also Antonisch 2010) or as an existential feeling state of feeling welcome or afforded social worth and value, as I argue here. May (2011) points to the possibility of belonging not being a desirable state, of opting out and actively choosing to reject mainstream social practices, this rejection involves choice and agency whereas nonbelonging, exclusion and misrecognition are external process of negation of personhood and social value. Antonisch (2010) and Yuval-Davis (2006) work towards the construction of a 'politics of belonging' which frames belonging as 'a discursive resource which constructs, claims, justifies, or resists forms of socio-spatial inclusion /exclusion' (Antonisch, 2010, p645). Whilst also being a 'discursive resource', belonging is fundamentally embodied, it is a feeling state negotiated in intersubjective relations with others, material environments and social structures. In this sense, Honneth's (2004) processes of recognition, of being recognized and afforded social worth is intimately connected to belonging.

Like toileting, citizenship is also relational - it links the individual to the collective, the self to the social (May 2011 see also Lister et al. 2007), the 'private' or personal to the 'public' or the political (Plummer 2003) and it does so via embodiment and through the feeling that one belongs, that one is accepted and that one is welcome. As such, citizenship is an embodied activity; it can be felt as belonging or not belonging and is a continuously negotiated experience encompassing all of the intimacies of everyday life. Private issues have always been intertwined with the 
state but have not been recognised as legitimate and meaningful components of what it means to be a citizen or to belong in society and the invisibility or invalidation of the 'private' sphere has emerged from the 'tendency to think in dualistic terms about public and private - the need to define oneself in opposition to, in rejection of, and in a hierarchy with something else, rather than in connexion to it' (Prokhovnik, 1998, p87).

\section{In and Out of Control Citizens: constituting who belongs}

As already discussed being seen to belong is linked to what kind of bodies we have and, as this paper will go on to argue, the extent to which we are perceived to have control over our bodies and physical actions. Bacchi and Beasley (2002) assert that enjoyment of full citizenship is dependent on the distinction between the 'control over' or 'controlled by' body subject. Much like Shildrick and Price (1999), Bacchi and Beasley (2002) assert that the less control one has over their body the more regulation and exclusion they face. This is particularly salient for disabled people whose 'out of control' bodies are determined as dependent and lacking autonomy. Control, they argue, is associated with political autonomy in keeping with the construction of the active, productive citizen (Turner 1993). Goffman $(1972,1978)$ and Giddens (1991) have also considered the relationship between the citizen and the 'controlled' or contained body. Featherstone \& Hepworth (1991) discuss the contained/competent citizen in relation to the control of bodily excretions:

Loss of bodily controls carries similar penalties of stigmatisation and ultimately physical exclusion...Degrees of loss impair the capacity to be counted as a competent adult. Indeed, the failure of bodily controls can point to a more general loss of self-image; to be ascribed the status of a competent adult person depends upon the capacity to control urine and faeces.

(Featherstone \& Hepworth,1991, p376).

Being in control of your body has formed a central part of how the rational, good citizen is constructed, and as Elias (2000) highlights, being in control of how we 
manage our bodily waste (without mess, privately and in solitude) reinforces the idea of the civilised person. Agency, personhood and status are afforded to those who are seen to be more in control of their bodies. Giddens (1991) assesses that competency and agency are held by those who are 'in control' of their bodies and argues that 'routinised control of the body is crucial to the sustaining of the individual's protective cocoon in situations of day-to-day interaction' (Giddens 1991, p56). The active citizen, according to Turner (1990, p209), acts deliberately, rationally and publicly - it is this deliberate, controlled agency that defined 'him' as an active (although disembodied) citizen-agent. Toilets, what happens in them or perhaps more accurately toileting for those who don't require a standard cubicle or urinal (Gerhenshon \&Pennar 2009; Greed 1995), then, are identified as falling outwith the realms of what citizenship is as they are spaces where unbounded, unsanctioned and leaking bodily processes are enacted and experienced by bodies that challenge social discourses of control and ability. Worse still is when these processes of leaking occur outside of the bounded space of the toilet.

\section{Disabled Toilets in Disability Studies}

Disability scholars' preoccupation with and dedication to uncovering experiences of inequality in 'public' spheres are, in part, formed through disability studies' close relationship to the disabled people's movement and articulate the longstanding and ongoing exclusion of disabled people from public spaces. I will not reinvent the wheel here, but the consequence of the (arguably necessary) rallying cry 'disabled by society, not by our bodies' (Shakespeare $\&$ Watson 2002) was the denial of disabled people's bodily experiences, of impairment and its material realities and the myriad 'private' and intimate everyday experiences that disabled people live. The critique of this neglect, primarily by feminist scholars (Crow 1996; Morris 1991 and Thomas 1999, 2001, for example) led to a notable theoretical and empirical shift towards the 'back regions' of disabled people's lives (see Be 2012; Hughes this volume; Malacrida 2012; Thomas 1999, and Shakespeare 1996 for examples). Shakespeare writes that in order for disabled people to achieve inclusion then 'reconciling the public and the private also means connecting the individual 
experiences of the body, to the collective experience of social structures' (Shakespeare, 2000, p165).

The sociology of everyday life neatly underpins the rationale behind the importance of looking at the quotidian, the mundane as sources of hidden inequalities that are disassociated from how citizenship is constructed but form the most enduring and pervasive experiences of discrimination. The socio-spatial exclusion of disabled people, specifically in relation to toilets, was dealt with in some detail by Kitchin and Law (2001). They argue that the construction of disabled toilets and lack of provision limits the way in which disabled people can participate in public life. They usefully introduce Cooper et al's (1998) notion of 'the bladder's leash' - the idea that disabled people's participation is constrained and contingent upon their ability to 'hold it in' or not (Kitchin and Law 2001). They explain that the exclusion of disabled people from public participation via toilet exclusion is formed through the engineering and design of toilets in the first place. They maintain that 'architects, planners and builders until very recently have been under no obligation to provide accessible toilets in public spaces and buildings' (Kitchin and Law 2001, p290). Bichard and Knight (2011) have worked to examine the provision of public toileting spaces that are widely accessible and mapping these spaces to make more visible accessible toilets in the UK. There have been important ethnographies on managing life with a stoma (Manderson 2005) and the way that managing toileting with a stoma shapes everyday experiences.

Latterly, Slater et al. (2016) and Liddiard and Slater (2017) have brought disabled toileting back into focus through discussions of safe toileting spaces, queer and disabled toileting spaces in schools and through concepts of 'containment'. Liddiard and Slater (2017) draw on ableist normative constructions of corporeal containment as discourses that position leaking, volatile, disabled and gendered bodies as socially problematic and deviant. The normative discourse of containment brings 'control' to the fore; critically reminding us that control is equated with social acceptability (Liddiard \& Slater, 2017, p13) and as discussed earlier, citizenship and participation. 
Serlin (2010, p179) charts a social history of disabled toilet activism in the U.S and the design of American disabled toilets. Disabled toilets, in the American context, are linked to concepts of dependency and of (non-male) problematic bodies. Serlin evidences the separation of men's toilets from disabled and women's toilets (that go together), thus making public statements about the social roles and status of women and disabled people as dependent, as caregivers and men as efficient, independent, contained, solo-excretors. For Kitchin and Law (2001) and Serlin (2010), then, the toiletscape or how disabled toilets are imagined, laid out, their construction and architecture say something about what kind of citizens disabled people are. What limited scholarship on disabled toilets does tell us is that bodies and toilets matter and that they matter in relation to how we negotiate everyday public life.

Not only do toilets matter for citizenship, but how we excrete matters too. It shapes our experience of belonging and personhood. As Elias' civilising process outlines, embarrassment, shame and revulsion must be learned to cultivate appropriate bodily conduct and social manners (Elias 2000; Inglis 2000). This shame and failure to control the body is felt and, importantly, disgust is directed at those whose bodily excretions are not managed in ways seen as appropriate (Hughes 2012 see also Lea 1999). Manderson (2005) explores the use of stomas, bowel and bladder incontinence for men and women and how this is managed in sexual encounters. Control, again, comes to the fore as leakiness structures everyday experiences of toileting in the face of 'social attitudes of pity and curiosity' (Manderson, 2005, p112). Normative discourses of excretion and acceptable bladder and bowel management, for Manderson's participants, structured their sense of self, selfesteem and belonging as competent adults:

Individuals with limited bladder or bowel control to an extent are repositioned as child-like, at times needing the kind of care provided to a child and dependent in ways contradictory to constructions of adulthood and adult social relations

(Manderson, 2005, p408). 
Impairment, leaky and gendered bodies disrupt the contained citizen toilet-goer and as such are afforded and provided with fewer, inaccessible and useable disabled toilets as a result. Appeals for more women's toilets have centred on the multiple and particular needs that women have for increased and dedicated toilet space. Women not only piss and shit, they also menstruate. They have pregnancies. Women are more likely to have cystitis, urinary tract infections and frequently use toilets in which to breastfeed (mitigating further socio-spatial taboos and barriers) (Plaskow, 2008, p54). Disabled people also require more, accessible, specifically designed toilets to manage the corporealities and impairments that shape their toileting and menstrual needs, to fit wheelchairs, scooters and other mobility aids, to allow suitable space for personal assistants, partners, supporters and children and to have baby changing facilities that disabled parents can also use. In recognition that disabled people are also parents, grab rails, hoists, and changing beds are also required. To be sure, women have fewer dedicated and appropriate toileting spaces, transgender people fewer still and disabled people even less. Disabled people require not only the recognition that equality, in practice, means toilets but it also demands spending, resources, design and consultation.

\section{Research methods and data}

The data presented in this paper was collected as part of my $\mathrm{PhD}$ research undertaken between 2009 and 2014 at the University of Glasgow. The research is comprised of 31 interviews with 18 disabled young people, aged 18 - 30, in Scotland.

I conducted semi-structured interviews over a period of 15 months. I employed feminist phenomenological methodological approaches. A feminist approach allowed for examining dualistic social and political discourse, well understood in terms of women's oppression (more generally), and less well problematized in relation to disabled people's everyday experiences of toileting. Feminist phenomenology undertakes the possibility of challenging oppressive social practices with a focus on corporeality and lived experience (Baird \& Mitchell 2014, Young 1990). In addition, employing a feminist phenomenological epistemology made space for reflexivity, 
researcher positionality and exploring the role of reciprocity in this paper (England 1994, see also Finlay 2002). Further, feminist emancipatory paradigms (Stanley \& Wise 1990) have been crucial in informing disability emancipatory research, feminist methodologies make space for exploring the shared ontologies of oppression that shape experiences of gender and disablement from the standpoint of disabled people themselves (Morris 1992, Smith 1990).

The research was focused on young people with physical impairments. I didn't ask what participants' impairments were and nor did I stipulate a criterion for what a physical impairment was. Participants self-identified as disabled. In this paper, I make reference to my own experiences as a disabled toilet 'goer' because it formed part of the reciprocal approach that I took when interviewing participants (England 1994). I asked questions about them, their bodies and citizenship and they asked me questions about mine. Recognition of this is essential (Ramazanoglu \& Holland 2002).

\section{Disabled Toilets: private acts, public spaces}

I didn't consider toilets when I began this research. I didn't consider them in relation to where me and my participants met to have interviews. I didn't think about toilets in relation to my own toileting needs during the process of data collection. Toilets and toileting were so invisible to me that the only time I thought about them was when / needed to go. So, when participants brought up toilets, and needing the toilet, in almost every interview, suddenly toilets became acutely visible and at the heart of what we were talking about in relation to citizenship, and bodies in 'private' and 'public' spaces. In conversation with my participants I became aware of my own enacted citizenship, my barriers to accessing public spaces, my anxieties over where toilets will or won't be, and the unconscious mapping of spaces in relation to where I could or couldn't 'go'. The following sections of this paper will address and examine participants' experiences of inclusion and, more commonly, exclusion, in relation to their everyday toileting experiences. 
Using public disabled toilets: where toilets exclude

Disabled toilets were unpredictable, precarious spaces for most, if not all, participants. Frequently participants were confronted with toilets used as storerooms, or cleaning cupboards. They were often too small to fit wheelchairs or mobility aids or there weren't any accessible toilets present at all. As Kitchen \& Law assert, disabled toilets are about disabled people being able to participate in public life, or as Fraser argues, about 'participatory parity' (2008). However, they are also about recognising that citizenship is a lived, felt experience of sharing space with non-disabled people, and this recognition of being of value is felt as belonging. For citizenship and rights to be more than mere abstractions the 'social flesh' of citizenship must be acknowledged (Bacchi \& Beasley 2000; Kitchen \& Law, 2001, p289). Physically not 'fitting' into a space had destructive effects on participants' sense of self and value. Pete explains his experience of needing the toilet when out and the barriers that he sometimes faces:

P: You're in a pub and if you're drinking pints you need to go to the toilet. And they're [staff] like 'oh you'll probably fit into the gents toilet'. So you try but you can't and your chair won't fit in the cubicle and when I don't have my leg on I have no option but to go. I've had to go other places, I've had to leave one pub and go to another one to use a toilet just to come back and when getting annoyed at the pub they're like there's nothing I can do about it' or when you do find a pub with disabled toilets they're full of crap like a store room.

(Pete, 26)

Participants' ability to go to the toilet, in public space, is dependent on the provision of adequate public toileting spaces. Private acts become a public matter, a matter of inclusion and being excluded from taking part in social activities, going to the pub or 'drinking pints' is felt as destructive to the self and to a person's sense of social value or 'belonging'. Pete experienced inaccessible toileting, internally, as a burdensome body, as someone deviant who did not belong in the same leisurely spaces as 
nondisabled others. Lack of recognition of his basic needs - profound matters of equality and citizenship - prayed on Pete's self-esteem:

Ph: So how does that make you feel?

P: It makes me feel embarrassed and I get annoyed at myself for being embarrassed because I don't feel I should. I haven't done anything wrong, but I feel like such a burden, I feel like such an inconvenience and it also means that you become a point of attention to people, people notice you and it becomes an ordeal and it shouldn't be. You should be able to go up and go to a toilet without having the whole of a restaurant looking at you. So yeah it makes me frustrated and I do get angry about it, but I tend to not say anything. I get annoyed, but I won't say something because people will look at me and go 'oh he's just one of those bitter disabled people who needs to shout about it all' you know?

(Pete, 25)

Nonbelonging, in this example, was entangled with visceral and corporeal experiences of frustration, anger and shame which ultimately resulted in damage to Pete's sense of self. As such, material environments that are structured through exclusion are intimately tied to phenomenological experiences of that space and how personhood is negotiated in those spaces.

Meg spoke about the composition of disabled toilets and felt that sometimes the space served to construct ideas about her body and its perception as disgusting. The lack of mirrors in disabled toilets made some participants feel that their bodies were so out of the bounds of belonging, so revolting that mirrors were not necessary:

M: Another thing that pisses me off in my day to day life is that disabled toilets never have mirrors as if because you don't need to, or you don't want to look at yourself because of your hideous disability (laughs) so yeah so that really annoys me. 
(Meg, 29)

The design and construction of toileting spaces shape how citizenship is articulated, felt and embodied and makes social and political statements about which bodies belong and which don't and for Meg, this belonging is structured through the prism of disgust. The ableist toiletscape that Meg is confronted with tells a story of nonbelonging, of being 'in' public spaces to which disabled people have no claim. Thinking back to the construction of the citizen in modernity, ableist toiletscapes refract a narrative of corporeal order that disabled people are seen to not conform to producing a framework of citizenship that is unattainable.

\section{The 'bladder's leash'}

Kitchen and Law explicate the relationship between the body and the role of public toilets when they note that "Without accessible toilets, people are subject to 'the bladder's leash' (Cooper et al.1998), restricting how long they are able to stay in a place and thus constraining their participation" (Kitchen \& Law, 2001, p289). The 'bladder's leash' was perhaps the most visceral manifestation of exclusion that participants articulated. It represented lengths that participants would go to, to regain, what they articulated as, control of their bodies in precarious environments in environments where they felt out of control:

If I'm going out, unless I know where the toilets are and that they're good ones that I can use, I won't drink. I can sometimes go the whole day without drinking and it's only when my pee is nearly black that I realise how bad it is, it smells so strong. I do it because I can be pretty sure that if I don't drink then I won't have to deal with needing the toilet and one not being there. I can't explain it, not drinking... it makes me feel safe. Safe in myself. It takes away the not knowing. It's worth it for that. Otherwise I couldn't go out for long.

(Ella, 25) 
Making the unpredictable (not knowing where a toilet was or if it was usable), predictable (by limiting fluid intake) provided a sense of control over the bladder and the environment and ameliorated the feelings of anxiety and disappointment of not finding good toilets. It was a strategy used, by participants, to avoid feeling unwelcome and devalued; avoiding this rejection came at a great corporeal cost.

Many of the participants spoke about the process of using public disabled toilets. A large number of disabled toilets in the UK remain locked and can only be accessed by a 'Radar' key (Kitchen \& Law 2001) under the National Key Scheme² (NKS). This means that when a disabled person needs to use a public toilet they often have to go to another shop or location where they can collect the key. Furthermore, in many cases you are asked to wait at the toilet while the shop assistant brings it over to you. This ensures that Radar keys don't go missing and ironically justified through discourses of keeping disabled toilets clean for disabled people - essentially disguising disadvantage as privilege. Disabled people can buy radar keys online to access disabled toilets across the UK, and so paying for the privilege to go to the toilet. 'Going to the toilet' is, therefore, contingent on a number of factors: access to a disabled toilet; access to a radar key; and waiting for someone to unlock a toilet for you. These contingencies compound the notion of the 'bladder's leash' (Cooper et al. 1998).

Meg discusses the process of using a public toilet when a radar key is required:

M: ....y'know disabled toilets get used as a store room a lot and it does my brain in and then you have to wait an extra five minutes while you're already desperate for the toilet for them to move everything ... but I have a key... do you have a key [meaning Radar Key]?

\section{P: No I don't have one}

M: I have one...but I got it through means I rather wouldn't mention (laughs).

(Meg, 29)

\footnotetext{
${ }^{2}$ The National Key Scheme is detailed here: $h t t p: / /$ radar-shop.org.uk/Detail.aspx?id=0
} 
When participants discussed inaccessible, disabled, toilets it was almost always in retelling how these toilets were used as cleaning cupboards - to store the cleaning products, mops and buckets used to clean the space. In this sense disabled people were given less status than that used to remove dirt. Conversion of disabled toilets into storage space also requires additional self-control. For Meg, a Radar key although she refused to pay for it - means that toilets become more accessible as disabled toilets become more available to her. My own experiences with radar keys and locked toilets have given me some insight into the difficulties that one can encounter if the key to relief is held by another. Locked toilets demand strategies that pre-empt 'need'. If you wait until you need or if you are 'desperate' then being confronted with a locked toilet and not knowing where to get the key, or waiting for someone to bring the key causes deep, visceral anxiety over the potential consequences of waiting for the door to be unlocked: control evaporates:

$R$ : ... if you're going to a bar... the bar may be on the ground floor, but the toilets might be downstairs. Or sometimes if they do have a disabled toilet it will be full of all the cleaning supplies and stuff and I get so frustrated sometimes. Obviously, you'll know yourself, but I hate it when you have to go to the disabled toilet and it says that you have to go and get a key and you have to go somewhere miles away to get the key and then go back...I'm so embarrassed to say this but I've very nearly had accidents. I'm an adult.

(Ruby, 26)

Not only does the key require that one must 'hold it in' but one must also announce ones need publicly to the key-holder and be beholden to that person's convenience. As Ruby's story shows, dependency on the key-holder is highly precarious and signals loss of control. It takes us back to the association of bodily containment with purity and belonging, but here we can see that additional pressures are placed on disabled people's bodies often making containment impossible. Ruby's story also brings to life Bacchi and Beasley's (2002) 'controlled by body' subjects; a toilet, under surveillance, locked and monitored, subjects disabled people to the indignity of unnecessary help, to the willingness and/or priorities of anonymous, nondisabled 
others. What is a key or a locked toilet door if not a clear sign of being 'locked out', a clear sign of unwelcomness. In 2017, Paralympian Anne Wafula Strike described her experiences of 'wetting herself' on a train ${ }^{3}$ :

"I was completely robbed of my dignity by the train company," she said. "I would like to ask the train company when will they give me my dignity back? As a disabled person, I have worked so hard over the years to build up my confidence and self-belief.

"Having access to a toilet, especially in a developed nation like the UK, is one of the most basic rights. I tried to conceal the smell of urine by spraying perfume over myself. When I finally got home after my nightmare journey, I scrubbed myself clean in the shower then flung myself on my bed and sobbed for hours."

Strike's experience brings to the fore the implications on self-value and feelings of belonging when there is no or poor toilet provision and also on the normative ideal of containment and control as tenets of competent citizenship. Strike talks about rights and bodily disgust in relation to her experience of being 'caught short', what is apparent is that there is a complex relationship between impairment and toileting needs and material environments that make losing 'control' possible, and social norms of bodily containment are made impossible in these kinds of scenarios. This challenges the notion that disabled bodies are 'out of control' bodies but rather their citizenship is denied because they are excluded from ableist landscapes and spaces. Disabled bodies, then, are refused citizenship through poor toilet provision.

\section{Inclusive Toilets}

Where public disabled toilets were made accessible for participants it represented their inclusion at more than just an ideological level. They were able to take part because they had adequate provisions for daily embodied activities. Some

\footnotetext{
${ }^{3}$ Guardian article accessed (August 2017) to be found at: https://www.theguardian.com/society/2017/jan/02/paralympian-anne-wafula-strike-wet-herself-trainno-accessible-toilet
} 
participants described their experience of accessible toilets and how it made them feel included on the whole:

P: In what ways do you feel you're treated better? [At College rather than school]

M: Well just in school I was always bullied in some sort of way and they [at college] just treat you as if you were anybody else...just like anybody else. If there's something wrong they'll fix it for you to make it accessible, like there was a toilet that was downstairs, and it was a disabled one but if I wanted another one somewhere else then they'd get me another one somewhere else.

(Molly, 18)

Accessible toilets, for Molly, were juxtaposed with her negative experiences of school - her feeling 'just like anybody else' was realised through accessible toilets and provision for her in a public space. Again, Molly's inclusion and participation was felt through her capacity to use the toilet without issue 'just like anybody else'; a sense of belonging in that space was integral to having citizenship in the full sense.

For J ack, a disabled athlete, the presence of 'disability sports' in mainstream sporting arenas is articulated through the provision of accessible toilets and changing areas for disabled athletes:

J: I think a lot of them [sports centres] are geared up for playing wheelchair sports in the facilities so obviously a lot of thought goes into changing facilities, toilets... they've all got them - some places could be doing with more especially when there's like a wheelchair tennis tournament and everyone's in the toilet at the same time and there's only two toilets. I think they certainly have made the effort to make things accessible and I think a lot of that is to do with the fact that you know a lot of them do host wheelchair events...

(Jack, 22) 
Greg explained how accessible toilets made life easier, how it meant that less time had to be dedicated to going to the toilet and furthermore how it made taking part in wheelchair sports easier when the toilets were accessible:

G: well playing the rugby ...it's a case of 'oh where's the toilet' and there's a toilet out and round the corridor and you won't get in it in your sports chair but you might get in in your everyday chair. Even in your everyday chair you might not get in so where's the disabled toilet and then you have to go down the hall, through a door, down a ramp, through another door and then push a button to get through to the accessible toilet and you think well that's no good it's a complete waste of time BUT when we went into T' [another city gym] gym and everything was all flat and you go into the hall and the disabled toilets are right there and you can get in in your sports chair, that's amazing. I felt like I was meant to be there.

(Greg, 28)

Greg's exclamation 'I felt like I was meant to be there' is an exclamation of feelings of belonging, of participatory parity in citizenship. If citizenship, as I argue, is the phenomenological feeling of belonging, then access to toileting spaces constituted the material expression of Greg's inclusion in citizenship. Words and phrases such as 'meant to be there' and 'just like anybody else' structure the feelings of being at home, accepted and welcomed by the society you live in and the others that are in it with you (May 2011), the feelings of recognition of being of value (Honneth 2004) and as Miller argues ' the quintessential mode of being human...'(Miller, 2003, p218).

While not part of the experience of using public toilets, Greg explained that going to the toilet was critically linked to the possibility of obtaining and sustaining employment. He is a professional basketball player and had acquired a spinal cord injury in his early twenties. Greg used a catheter on a daily basis to manage his bladder and bowel.

If I have an accident I have to leave work. When I was working full time before I had a problem it wasn't a case of just nipping home it was a case of 
driving 30 miles to get home and then get sorted and get back into the car, get back to work to finish my shift. I hate not working; I want to get back into employment. I could work at the moment, but it would be a case of working and not knowing what could happen.

(Greg, 28)

Greg's story further points to the temporal dimensions that shape his toileting experiences. He needs more time to manage the equipment that he uses to go to the toilet and this does not fit well with expectations of productivity in modern capitalist societies. Inglis \& Holmes (2000) discuss the relationship between excretory needs and the factory clock and the requirement of workers to exert 'control over' their bodies to fit in with the allocated toileting times. Whilst Greg's excretory practices occur via catheterization, the catheters can be unpredictable. They can break or malfunction. They can leak, resulting in smells and stains and they can cause him injuries that he subsequently has to manage. Greg spoke of, for a long time, not being given the right sized catheter which meant he was constantly managing the damage that this caused to his body on top of the visible signs of urine on his clothing. Excretion exclusion robs bodies, that don't excrete by the norms of discretion, of citizenship status. Here, it compromised Greg's employment and left him out of work which shaped contributed to him constructing a sense of his disabled self as burdensome and as not belonging:

It's just life now... life as a disabled person. I'm too different.

(Greg, 28)

Toileting, and how it is managed, is a crucial part of Greg's sense of 'fitting in', of feeling sewn into the fibre of a society in which he is part and more crucially, welcomed. Greg characterized his life as a disabled person as one where his toileting was always at the fore of his experiences and daily life, his perceived lack of control over his body, made worse by his lack of sensation or feeling of his excretory processes, led him to feel like he was a burden upon a society that values productivity, control and able-bodiedness as mechanisms or proof of belonging. 
Disabled people's excretory processes are in a constant state of 'dys-appearance' (Leder 1990) and everyday toileting practices are constrained due to material toiletscapes. As such disabled people are structured into categories and ways of being that render their citizenship simultaneously invisible and visible as being outwith modernity's 'dream of purity' (Bauman, 1997, p5).

\section{Conclusion}

Citizenship, bodies, toilets and disability - the complicated intersections at which these concepts meet - reflect the complexities of disabled people negotiating everyday toiletscapes. The crux of this discussion has been to use disability as a lens through which to view citizenship as embodied in a sense of belonging; to recognize toilets and toileting as a lived experience at the heart of what it means to be welcomed and to describe the continued exclusion of disabled people from 'full citizenship' through the absence of or poor toilet provision. This was an effort to build upon the work that has been done to show toilets as a hidden site of inequalities (Browne 2004; Cavanagh 2011; Gershenson \& Pennar 2009 and Greed 1995) and to address the lack of focus, within disability studies, on the 'social flesh' of inclusion on a daily basis.

Contesting dualisms and binary thinking have been the backbone of so much sociological inquiry; there is, as Bacchi and Beasley (2002) argue, a great need to demonstrate the very real outcomes of contemporary forms of social reality founded on dualistic thinking. This discussion has gone some ways to 'pulling together' the fractures or distances between citizenship and the body and disability and toilets to make more visible the invisible forms of inequalities, inequalities in the back regions, of disabled people's lives.

All participants sought to overcome the perceived 'failure' to manage their excretions, to make the unpredictable, predictable by exerting 'control over' their bodies. This was an effort to belong, to overcome the feeling of not belonging, to avoid the anxieties that pervaded being in public spaces and not knowing where a toilet was, or if it was locked or not or filled with chairs or cleaning products or its use required 
permission from a keyholder. As Lea writes 'This 'normal' body is briefly described as one which shits discretely, appropriately and un-problematically, and does not involve anyone else in the process' (Lea, 1999, p7). Participants sought to make themselves competent social agents, in control of their bodies and excretions to negotiate lack of provision and being 'locked out' of citizen practices.

Everybody everywhere needs to pass waste; it is a fundamental and universal human experience and need. Whilst the ways in which people excrete are not universal, the fact that everybody does is bound crucially to our experiences of the world and of our-selves in the context of our citizenship and our value in relation to others. To not be recognised and thus not provided for, as a person who excretes and needs a place to do so, is among the most resounding and damaging forms of denial that a person or group of people might experience.

\section{Acknowledgements}

I would like to thank all of the participants who form the core of this research, and for sharing with me their experiences of toileting and belonging. Thanks to Lucy Pickering and Sarah Armstrong for their guidance and editorial support. Particular acknowledgements to the University of Glasgow for supporting the $\mathrm{PhD}$ that made this research possible.

\section{References}

Abrahams, Naeemah, Shanaaz Mathews, and Petunia Ramela. 2006. "Intersections of 'sanitation, sexual coercion and girls' safety in schools." Tropical medicine \& international health 11(5): 751-756.

Antonsich, Marco. 2010. "Searching for belonging - an analytical framework." Geography Compass 4(6): 644-659.

Appadurai, A. (1990). Disjuncture and difference in the global cultural economy. Theory, culture \& society, 7(2-3), 295-310. 
Bacchi, C. \& Beasley, C. 2000. 'Citizen Bodies: embodying citizens - a feminist analysis', International Feminist Journal of Politics, 2(3): 337-358.

Bacchi, C. \& Beasley, C. 2002. Citizen bodies: is embodied citizenship a contradiction in terms? Critical Social Policy 22: 324

Baird, K. M., \& Mitchell, T. (2014). Using feminist phenomenology to explore women's experiences of domestic violence in pregnancy. British journal of midwifery, 22(6), 418-426.

Barnes, C \& Mercer, G. 1997. 'Introduction' in C Barnes and G Mercer (eds) Doing Disability Research. Leeds: Disability Press.

Barton, L. 1993. 'The struggle for citizenship: the case of disabled people' Disability, Handicap \& Society. 8(3):

Bê, A (2012) 'Feminism and Disability: a cartography of multiplicity' In Watson, N., Roulstone, A., \& Thomas, C. ed. Routledge Handbook of Disability Studies (Routledge, London)

Bichard, Jo-Anne, and Gail Knight. Publicly accessible toilets: An inclusive design guide. Royal College of Art Helen Hamlyn Centre for Design, 2011.

Browne, K. (2004) 'Genderism and the Bathroom Problem: (Re)Materialising Sexed Sites, (Re)Creating Sexed Bodies' Gender, Place and Culture 11(3): 331-346.

Cavanagh, S. (2011). Queering Bathrooms: Gender, Sexuality and the Hygienic Imagination Toronto: University of Toronto Press.

Chalfin, B. "Public things, excremental politics, and the infrastructure of bare life in Ghana's city of Tema." American Ethnologist 41.1 (2014): 92-109.

Cooper, A, Law, R, Malthus, J and Wood, P. (2000). 'Rooms of their Own: Public Toilets and Gendered Citizens in a New Zealand City, 1860-1940' Gender, Place and Culture 7(4): 417-433. 
Crow, L. (1996) 'Including all of our lives: renewing the social model of disability' In J. Morris ed. Encounters with Strangers: Feminism and Disability (Women's Press, London)

Douglas, M. (1966) Purity and Danger: An Analysis of the Concepts of Pollution and Taboo (London, Routledge and Kegan Paul)

Elias, N. (2000) The Civilizing Process: The History of Manners and State Formation and Civilization (Blackwell, Oxford)

England, K. V. (1994). Getting personal: Reflexivity, positionality, and feminist research. The Professional Geographer, 46(1), 80-89.

Featherstone, M. \& Hepworth, M. (1991) The mask of ageing and the postmodern lifecourse', in Featherstone M, Hepworth, M., Turner, B.S. ed. (1991) The Body: social processes and cultural theory, (London, Sage)

Fraser, N. (2003) 'Social justice in the age of identity politics: redistribution, recognition and participation', In N. Fraser \& A. Honneth ed. Redistribution or Recognition? A Political-Philosophical Exchange (London \& New York: Verso)

Fraser, N. (2008), Scales of justice: Reimagining political space in a globalizing world (Polity Press, Cambridge)

Finlay, L. (2002). Negotiating the swamp: the opportunity and challenge of reflexivity in research practice. Qualitative research, 2(2), 209-230.

Gershenson, O. and Penner, B. (2009). 'Introduction: The Private Life of Public Conveniences' in O Gershenson and B Penner (eds) Ladies and Gents: Public Toilets and Gender, Philadelphia: Temple University Press, 1-34.

Giddens, A (1991) Modernity and Self-Identity: self and society in the latemodern age (Stanford University Press)

Goffman, E. (1972) Relations In Public, (Penguin, Harmondsworth) 
Goffman, E. (1978) Response Cries. Language Vol. 54, No. 4. (Dec. 1978), 787-815.

Grear, A. (2006) Human Rights - Human Bodies? Some reflections on corporate human rights distortion, the legal subject, embodiment and human rights theory. Law Critique (2006) 17:171-199

Greed, C. (1995). 'Public Toilet Provision for Women in Britain: An Investigation of Discrimination against Urination' Women's Studies International Forum 18(5-6): 573584.

Grosz, E. (1994) Volatile Bodies: Toward a Corporeal Feminism, (Bloomington, IN: Indiana University Press)

Habermas, J. (1989) The Structural Transformation of the Public Sphere: An Inquiry into a Category of Bourgeois Society (Cambridge, MA: MIT Press)

House, S., Mahon, T., Cavill, S. (2012): Menstrual hygiene matters. A resource for improving menstrual hygiene around the world. London: WaterAid. https://www. wateraid.org/uk/why-wateraid

Hughes, B \& Paterson, K (1999). Disability Studies and Phenomenology: the carnal politics of everyday life in 'Disability \& Society', Vol. 14, No. 5, 1999, 597-610

Hughes, B (2004). Disability and the Body, 63-69, In J. Swain, V. Finkelstein, S. French, and M. Oliver ed. Disabling Barriers - Enabling Environments (London, Sage)

Hughes, B (2009). Wounded/monstrous/abject: a critique of the disabled body in the sociological imaginary, Disability \& Society, 24:4, 399-410

Hughes, B (2012). 'Fear, pity and disgust: emotions in the non-disabled imaginary' In Watson, N., Roulstone, A., \& Thomas, C. ed. Routledge Handbook of Disability Studies (Routledge)

Hughes, B (2012a) 'Civilising Modernity and the Ontological Invalidation of Disabled People' In Goodley, D., Hughes, B. and Davis, L. ed. Disability and Social Theory: New Developments and Directions (Palgrave MacMillan, London) 
Inglis, D., and Holmes, M. (2000). Toiletry time: Defecation, temporal strategies and the dilemmas of modernity. Time \& Society, 9(2-3), 223-245. .

Kitchin, R. and Law, P. (2001) The Socio-spatial Construction of (In)accessible Public Toilets. Urban Stud 2001 38: 287.

Lea, R. (1999). The Shitful Body: Excretion and Control' Medische Anthropologie 11(1): 7-18.

Leder, D (1990). The Absent Body, (University of Chicago Press, Chicago and London)

Lister, R. (2003) Citizenship: Feminist Perspectives (Basingstoke, Palgrave Macmillan)

Lister, R. (2007): Inclusive Citizenship: Realizing the Potential, Citizenship Studies, 11:1, 49-61

Lister, R., Williams, F., Anttonen, A., Bussemaker, J., Gerhard, U., Heinen, J., Johansson, S., Leira, A. \& Siim, B. (2007) Gendering Citizenship in Western Europe; new challenges for citizenship research in a cross-national context (The Policy Press University of Bristol)

Malacrida, Claudia (2012). Mothering and Disability: Implications for Theory and Practice In Watson, Roulstone \& Thomas (2012) ed. Routledge Handbook of Disability Studies

Manderson, L. (2005). 'Boundary breaches: the body, sex and sexuality after stoma surgery', Social Science \& Medicine 61 (2005) 405-415

Marshall, T.H. (1950). Citizenship and Social Class, (Cambridge, Cambridge University Press)

May, V. (2011). Self, belonging and social change. Sociology, 45(3), 363-378.. 
Mercer, K. \& Race, I. (1988). 'Sexual Politics and black masculinity: a dossier' In Chapman, R. and Rutherford, J. ed. Male Order, Unwrapping Masculinity, (Lawrence \& Wishart. London)

Morris, J. (1991). Pride Against Prejudice: a personal politics of disability (The Women's Press, London)

Morris, J. (1992). Personal and political: a feminist perspective on researching physical disability. Disability, Handicap \& Society, 7(2), 157-166.

Morris, J eds. (1996). 'Encounters with Strangers: Feminism and Disability'. (The women's Press, London)

Morris, J. (2005). Citizenship and Disabled People (London, Disability Rights Commission)

Oliver, M (1990). The Politics of Disablement, (London, MacMillan)

Oliver, M. (1996). Understanding Disability: From Theory to Practice, (London: Macmillan Press)

Pickering, L. (2010). Toilets, bodies, selves: Enacting composting as counterculture in Hawai'i. Body \& Society, 16(4), 33-55.

Plaskow, J. (2008). Embodiment, elimination, and the role of toilets in struggles for social justice. CrossCurrents, 58(1), 51-64.

Plummer, K. (2011). Intimate citizenship: Private decisions and public dialogues. University of Washington Press.

Prokhovnik, Raia. "Public and private citizenship: From gender invisibility to feminist inclusiveness." Feminist review 60.1 (1998): 84-104.

Ramazanoglu, C., \& Holland, J. (2002). Feminist methodology: Challenges and choices. Sage. 
Serlin, D. (2010) 'Pissing without Pity: Disability, Gender, and the Public Toilet' In Molotch, H. \& Norén (2010) eds Toilet: Public Restrooms and the Politics of Sharing (New York University Press)

Shakespeare, T., Gillespie-Sells, K., \& Davies, D. (1996). The sexual politics of disability: Untold desires. Burns \& Oates.

Shakespeare, T. (1997). 'Researching Disabled Sexuality’, In Barnes, C. \& Mercer, G. (1997) eds. Doing Disability Research' Disability Press (Leeds Disability Press)

Shakespeare, T. (2000). Disabled sexuality: toward rights and recognition. Sexuality and disability, 18(3), 159-166.

Shakespeare, T\& Watson, N. (2002) The Social Model of Disability: An Outdated Ideology?' In Exploring Theories and Expanding Methodologies, Vol.2, pp9-28.

Shakespeare, T. (2014) Disability Rights and Wrongs Revisited (Routledge, London)

Shildrick, M. \& Price, J. (1999) 'Openings in the Body: A critical introduction’ In Price, J. and Shildrick, M. (1999) ed. Feminist Theory and The Body (Edinburgh University Press)

Shilling, C. (2012) The Body and Social Theory'Third Edition, (London, Sage)

Smith, D. E. (1990). The conceptual practices of power: A feminist sociology of knowledge. University of Toronto Press.

Stanley, L., \& Wise, S. (1990). Method, methodology and epistemology in feminist research processes. Feminist praxis: Research, theory and epistemology in feminist sociology, 20-60.

Thomas, C (1999) Female Forms: Experiencing and Understanding Disability (Open University Press, Buckingham) 
Thomas, C. (2001) 'Feminism and disability: the theoretical and political significance of the personal and the experiential' In L. Barton, ed. Disability Politics and the Struggle for Change (London, David Fulton Publishers)

Turner, B (1991) 'Recent developments in the theory of the body' In M.Featherstone et al ed. The Body: Social Process and Cultural Theory (London, Sage)

Turner, B. (1993) 'Contemporary Problems in the Theory of Citizenship', in B.Turner ed. Citizenship and Social Theory, 1-17. London, Sage.

Weinberg, Jill D. 2009. "Transgender bathroom usage: A privileging of biology and physical difference in the law." Buff. J. Gender L. \& Soc. Pol'y 18: 147

Young, I. M. (1990). Throwing like a girl. Bloomington, IN, Indiana Press.

Yuval-Davis, Nira. 2006. "Belonging and the politics of belonging." Patterns of prejudice 40(3): 197-214. 